\title{
SPIRITUAL VALUES AND THE FAMILY IN COURT
}

\author{
ERTC F. MacKenziE*
}

The topic assigned for discussion in this paper is happily ambiguous. "Spiritual Values" may be interpreted as referring to religious teachings; but the term may equally refer to broad considerations of a purely social character.

First of all, it is here recorded that many millions of American citizens hold firmly to a purely religious judgment concerning the evils of divorce. They read the nineteenth chapter of the Gospel according to St. Matthew, verses three to twelve, and find there, not a mere record of the views of an ancient seer, but rather an authoritative decision proclaimed by the Incarnate Lawgiver for all mankind. God's authority, these citizens hold, is supreme. Against His law, no argument or authority may be cited. Hence, when a husband and wife are validly and sacramentally married, no man can put them asunder; and no court, by a bill of divorce, can endow them with a right to remarry. ${ }^{1}$ Under our American system, these citizens may hold these opinions, with others dissenting. They may by their discussions and their votes try to convince others to reform our existing legal institutions, so that divorce will not merely be regulated, but even eliminated.

This viewpoint, however, seems to be held by only a minority. The majority have other religious tenets in the matter of divorce, or none at all. A purely theological approach to the existing problem, therefore, offers little hope of a presently practical solution. This does not mean, however, that a restriction of divorce will be advocated solely by those who have theological convictions. On another plane, there are basic social values which strongly suggest and support a reforming attitude. Spiritual values, in this sense, involve no sectarian differences. All good citizens can consider these principles sincerely and fairly, and draw from them appropriate conclusions. Exposition of these values therefore forms the body of this paper.

Historically, every political society has recognized that the family is the essential and basic unit of social organization, and has given to it every favor and protection." This has been true in our own American legal history. Corpus Juris ${ }^{3}$ defines marriage as a status

* J.C.D., S.T.D., LL.D. Catholic Auxiliary Bishop of Boston.

${ }^{2}$ For a fuller but non-technical statement of Catholic viewpoint, see 52 Homiletrc aNd Pastonaz Rev. 888-896 (1952).

${ }^{2}$ Cf. The Soviet Family, I89 Atzantic Monthly 18-20 (1952) for a popularized report on the Soviet's reversal of public policy, from unlimited divorce to almost complete prohibition of divorce. The re-establishment of strong and legally protected families was dictated by a purely secularist and in. tellectual analysis of the needs of the state. Such authoritarian procedure is impossible in the United States; but it is here suggested that "the children of this world are wiser in their generation than the children of light."

${ }^{3} 38$ C. J. (Marriage. Definition and Nature $\$ 1$ ) 1273-I274 (1925), with authoritics cited. 
... in which the state is deeply concerned, and over which the state exercises a jealous and exclusive dominion.

Lombard $^{4}$ writes:

Marriage . . . is founded upon the mutual consent of capable contracting parties. It ... supersedes all other contracts between the parties and, with certain exceptions, it is inconsistent with the power to make any new ones. As between the immediate parties, it is a civil contract; but as between them and the State, it is a status controlled and regulated by considerations of public policy which are paramount to the rights of the : $x$ parties. $\therefore$ The Commonwealth has a deep interest to see that it is not put into jeopardy, but maintained. The marriage contract can neither be cancelled nor altered by the will of the parties.

These familiar legal phrases once applied literally and directly to the individual cases which arose. Today it is all too evident that they have chiefly a historical and nominal acceptance. Divorces by the hundreds of thousands are granted without investigation or contested trial. It is in the field of divorce practice, and there alone, that, notoriously, judicial decisions follow upon perjury and collusion, with no serious effort to prevent this perversion of justice. 5 It is admitted that divorce courts often cease to be tribunals to discover the truth and apply the law impartially, and rather are bureaus to register decisions already taken by the litigants. In these cases, therefore, the parties have effectually cancelled their status by their own will, general legal principles to the contrary notwithstanding.

The present problem is of modern growth, largely within the twentieth century, accelerated since the first World War. ${ }^{6}$ It had been in part sanctioned by statutes and by judicial procedures. For the most part, however, it derives from a change in public opinion. Despite criticisms and cries of alarm, the public has never rallied to oppose or check the liberalization of divorce. Amid this public apathy, many lawyers have found a substantial income from divorce practice, while judges and court officers owe their honors and status to the increase in the number of cases. Certain states attract libellants from afar, with profit not merely to courts and lawyers, but also to travel agencies, hotels, amusement centers, and all the rest. Naturally these vested interests have favored easier divorces. Also, millions of citizens, already divorced, have naturally tended to resist any movement which, by implication, would put blame on their character and social status. Finally there are many citizens of highest calibre who profess to be shocked and horrified by the statistical reports of divorce throughout the nation, but yet have upheld and defended individual cases among their personal acquaintance. These'cases, they insist, are purely private matters; the marriage bond had long been completely broken, beyond hope of repair; the continuance of the tie would do no good to anyone; no reasonable person would oppose the efforts of the unhappy wife or husband to find cited.

- Joseph Cummings, Marriage and Divorce Laws of Massachusetrs 3 (2d ed. 1937), with authorities ${ }^{\circ}$ Cf. dissenting opinion of Crane, J., in Mirizio v. Mirizio, 242 N. Y. $74,87,150$ N. E. 605,609 (1926).

-Walsh, Marriage and Civil Law, 23 ST. JoHN's L. Rev. 209 (1949). 
freedom and happiness in a new marriage. The theoretical condemnation of divorce in general has not persuaded these citizens to any judgment against divorce in individual cases.

Yet it is the repetition of these individual cases, by the hundreds of thousands, which gives us our horrifying statistical tables. It is an old human frailty to be unable to see the forest because of the trees. It is this concentration on individual cases which has made the public forget broad social implications. In contrast, this paper invites the readers of Law and Contemporary Problems, together with jurists, statesmen, leaders of public opinion, and all citizens of real vision, to remember that bad cases make bad law, and to consider values and purposes and procedures as they affect the common weal, omitting any personal and individual applications.

It is here submitted that social values call for a return to an older and stricter upholding of the permanence of the marriage bond. It has always been stated that the state has interests in every single marriage, interests which are paramount to the wishes of the parties themselves. No decision or statute, it would seem, has ever written into law the precise nature of this public interest. ${ }^{7}$ The reference was to a philosophy of society which was generally accepted, and hence needed no definition. Today, with a change in public thinking, it is well to recur to venerable and once familiar principles.

First, and basically, the public seems to have forgotten that the strength and vigor of national life depend directly on strong and vigorous family units; and, negatively, that decay in family life is a warning of national weakness, and of a vacuum into which some other race or nation will move, because of its superior strength and hardiness. Gibbon included this as a chief factor in his analysis of the decline and fall of the Roman Empire. The same historical correlation has been verified in other ages and other nations. In some part, this argument may involve a "cannon fodder" valuation of the family; but actually it extends to more than the mere number of youths available for military service.

There are spiritual values which, if lacking, leave the nation's citizens weakened in the essential courage and devotion and loyal will to serve the common weal; which, if present, cause an esprit de corps which makes invincible a people inferior in numbers and equipment. Commonly these values center upon hearth and home; are based on the devotion, the self-sacrifice, and the joy of possession and selfexpression which each man has known in his own family, and which he will not cede to any aggressor. There are those who, despite the heroism of our boys in Korea, cry that this consciousness of personal dignity and duty are lacking in our

\footnotetext{
T Some brief generalizations may be found, as: "Marriage is not merely a contract between the parties. It is the foundation of the family. It is a social institution of the highest importance. . . . The Commonwealth has a deep interest that its integrity is not jeopardized." French v. McAnarncy, 290 Mass. 544, 546, 195 N. E. 714, 715 (1935).

"The great object of marriage in a civilized and Christian community is to secure the existence and permanence of the family relation, and to insure the legitimacy of offspring." Richardson v. Richardson, 246 Mass. 353, 355, I40 N. E. 73 (1923), quoting Chief Justice Bigclow in Reynolds v. Reynolds, 3 Allen 605, 607 (Mass. 1862).
} 
society today. They argue that those who have nothing and expect nothing permanent or supremely valuable in their personal lives will have no high standards of devotion to their country, whether in peace or in war. One need not share in this pessimism; yet-if the home in which one was reared, and the home which one has established, were secure and beyond risk of dissolution, would one not have a greater stake in the preservation of such a happy fortune? Does not the present practice of thoughtless marriage and easy divorce threaten the foundations of patriotism and good citizenship? If so, who can resist a reform in the field of marriage and divorce? 8

A second consideration derives from the actual working of divorce courts. It will appeal chiefly to those who retain a personal conscience in the observance of the ethics of the legal profession, and who have an innate revulsion against perjury and deception in the judicial process. A bad tree brings forth bad fruit; and the value of an existing system may be judged by the evils which seem inextricable from its daily practice.

It was remarked above that the whole field of divorce litigation is malodorous. Deliberate perjury and misinformation are regularly presented to the courts, often by connivance of the respondents and their attorneys. Where the law calls for proof of the commissions of criminally guilty acts, whether of adultery or cruelty or whatever, actual practice is satisfied by specious technicalities, of no real truth or gravity. Where the statutes do not provide for an easy divorce, procedure makes available easy annulments.

It is commonplace that a majority of lawyers apologize for their participation in any divorce case. They state frankly that they wish to have no part in this field of practice. There is an implication that their brethren who make divorce a major or even sole activity are less than ethical. But may not a question be addressed to these barristers? Should they not use their influence and standing to correct a situation of which they thoroughly disapprove? Should they tolerate in silence the fact that a minority of lawyers bring the profession into disrepute by suborning perjury and all the rest? "Live and let live" is well enough in accidentals: it is cowardice or worse when essential standards of honor and truth are involved.

A third consideration derives from a psychological survey of the parties to any divorce, and their children. At present, with divorce and remarriage easily available, many marriages are rashly contracted. Sometimes the only basis for the marriage is a rash impulse, with no thought at all of the future. Often enough, for reasons easily imaginable, there is an intention to marry, but to terminate the union as promptly as possible. More often still, it is foreseen that a future divorce is entirely probable, but it is felt that some immediate satisfaction is more important than any later unhappiness. In all these cases, the guarantee of easy escape is a decisive motive for the unwise marriage. The elimination of this guarantee will not elimi-

\footnotetext{
${ }^{8}$ Pratrorm (May, 1952), published by Newsweek, New York, N. Y., gives a popular survey of the current divorce problem in the United States and the pros and cons of the newly proposed Family Court. In this reference, compare pages $2-4$.
} 
nate frailty and stupidity and rashness in our young people; but is it not socially wise and desirable to check, rather than encourage, whatever is rash and unthinking and destined to tragedy?

Again: each divorce or annulment sets a man and woman free from their mutual obligations, and free from the duties to society which they had formerly assumed. Each is given the right to remarry, and hence to undertake precisely the same obligations which on the xecord they had previously failed to fulfill. There are all too many cases in which a party is set free to repeat, with a new partner, the same mistakes and crimes which have already brought tragedy in the first marriage. Outside these cases, it is also true that the whole process of divorce will of its nature cause some psychological trauma even in honorable and generous and normal men and women. The shame of failure, the inevitable bitterness and hatred are hurtful, if not ruinous, to character. The hope of new happiness must be clouded by ever present memories of past disappointment. The new marriage suffers a serious psychological handicap.

If this be true of adults, it is even more true of their children. Those reared in a broken home can never have the background of safety, assured support, loving understanding, and the sense of belonging, which are essential to adolescent years. The balanced influence of both mother and father will be missing. It is all too obvious that the child in large part pays the price of the parents' quarrels and divorce. ${ }^{9}$ For the good, then, of the children, and even for the good of the parents themselves, there is need to halt the mad and uncontrolled rush from quarrel to libel, from libel to divorce, from divorce to remarriage.

A last consideration is found in the evidence that the simple device of delaying action on divorce libels has resulted in the withdrawal of the libel and the attainment of reconciliation. A significant number of people soon regret their first hasty action and gladly welcome any face-saving excuse to return and renew common life. With calm reflection, they come to see that divorce does not end problems, but rather creates new ones. It is thus proved that "divorce mills" do much unnecessary and avoidable harm to individuals, to families, and to the common weal. ${ }^{10}$

All this and more must be said of spiritual values which are neglected in the current granting of so many divorces. There have been many plans to work a reformation in law and procedure. The latest is discussed from many angles in this number of Law and Contemporary Problems. It must, however, be noted that the problem is really not one of drafting new statutes or introducing new procedures. The prevalence of divorce is due, not so much to the law and the courts, as to popular American opinion. Behind each of the divorce libels is the decision of one or both of the partners to file and prosecute the action; but behind this decision is the community judgment that these individuals are doing no wrong, and that it is for the partners to decide their individual futures. There is no remembrance of

'Id. at 4 .

${ }^{10} \mathrm{Id}$. at $\mathrm{r} 5$. 
the interests of the state "which are paramount to the rights of the parties." The problem therefore is one of education: how to create a general consciousness of social responsibility whenever the married status is assumed, and of similar social reponsibility whenever the status is endangered.

If American public opinion remains unconscious of any harm resulting from widespread and almost uncontrolled divorce, it is useless to write new statutes and install new procedures. However the law may read, publicly approved divorces cannot be denied to the millions of litigants. It is therefore a question of fact: have all these divorces actually harmed our United States? If not, there is little reason (other than religious) to urge reforming measures. But if harm has been done to the common welfare of us all, to wives and husbands and children, and to the dignity and purity of our judicial system, that fact must be proclaimed untiringly by all those who know the harm. On them rests the obligation to lead public opinion to a sounder and healthier judgment. The contemporary problem is whether or not they are able and willing to do so. ${ }^{11}$

${ }^{11}$ In The Spirit of Liberty-Papers and Addresses of Learned Hand Igo (Irving Dilliard ed., 1952), Judge Hand has written: "Liberty lies in the hearts of men and women; when it dies there, no constitution, no law, no court can save it. ..." So too for a spiritual valuation of marriage and the family. 